\title{
Penerapan Metode SMART (Simple Multi Attribute Rating Technique) dalam Pengambilan Keputusan Calon Pendonor Darah pada Palang Merah Indonesia (PMI) Kecamatan Tanjung Morawa
}

\author{
Ahmad Fitri Boy*, Dedi Setiawan** \\ * Program Studi Sistem Informasi, STMIK Triguna Dharma \\ *** Program Studi Sistem Komputer, STMIK Triguna Dharma
}

\begin{tabular}{l}
\hline \hline Article Info \\
\hline Article history: \\
Received May $31^{\text {th }}, 2019$ \\
Revised June $12^{\text {th }}, 2019$ \\
Accepted Augs $19^{\text {th }}, 2019$ \\
\\
\hline Keyword: \\
Sistem Pendukung Keputusan \\
SMART \\
Calon Pendonor Darah \\
Palang Merah Indonesia (PMI)
\end{tabular}

\begin{abstract}
Dalam pengambilan keputusan untuk menentukan calon pendonor darah pada Palang Merah Indonesia (PMI) Kecamatan Tanjung Morawa terdapat beberapa kesulitan yang dihadapi, diantaranya adalah keputusan yang diambil berdasarkan hasil dari proses medical check up yang terkadang tidak sesuai dengan hasil yang sebenarnya. Dimana dalam penyeleksiannya masih sering terdapat beberapa calon pendonor yang diizinkan mendonor tetapi tidak sesuai dengan persyaratan yang ditentukan oleh PMI Pusat. Metode yang dapat dipakai dalam pengambilan keputusan calon pendonor darah adalah metode SMART (Simple Multi Attribute Rating Technique). Metode SMART merupakan teknik pengambilan keputusan yang multiatribut dan fleksibel yang dapat membantu pihak Perusahaan dalam menentukan keputusan dengan cepat dan tepat. Untuk menentukan calon pendonor darah berdasarkan 4 kriteria yaitu : usia, berat badan, tekanan darah, temperatur tubuh, dan hemoglobin darah. Berdasarkan pada 4 kriteria tersebut disusunlah sistem pendukung keputusan dengan menggunakan metode smart, Sistem Pendukung Keputusan merupakan sistem komputer yang mengolah data menjadi informasi dan keputusan. Dengan dirancangnya Sistem Pendukung Keputusan menentukan calon pendonor darah menggunakan metode SMART ini maka pihak Palang Merah Indonesia (PMI) Kecamatan Tanjung Morawa dapat terbantu dalam mengambil keputusan menentukan calon pendonor darah.
\end{abstract}

Copyright $\odot 2019$ STMIK Triguna Dharma. All rights reserved.

\begin{tabular}{ll}
\hline First Author & \\
Nama & :Ahmad Fitri Boy \\
Kantor & :STMIK Triguna Dharma \\
Program Studi & :Manajeman Informatika \\
E-Mail & :masboy181@ yahoo.com
\end{tabular}

\section{PENDAHULUAN}

Darah merupakan cairan yang terdapat dalam tubuh makhluk hidup kecuali tumbuhan. Fungsi dari darah yaitu mengantarkan zat-zat dan oksigen ke jaringan-jaringan tubuh dan darah tidak bisa tergantikan oleh cairan lainnya. Jika manusia kehilangan banyak darah maka manusia pun akan meninggal dunia. Palang Merah Indonesia (PMI) Kec. Tanjung Morawa ialah sebuah organisasi yang bergerak dalam bidang kemanusiaan dan sosial yang merupakan bagian dari PMI Kab. Deli Serdang. Salah Satunya melayani pendonoran darah, setiap kantong darah yang diperoleh didapatkan dari masyarakat dengan sukarela datang ke PMI untuk mendonorkan darah dengan tujuan kemanusiaan. PMI Kec. Tanjung Morawa memiliki ketentuan - ketentuan untuk menjadi pendonor darah yang harus dipenuhi agar bisa mendonorkan darahnya. Dalam proses penentuan kelayakan pendonor darah, petugas PMI Kec. Tanjung Morawa melakukan medical check up untuk mengetahui berat badan, temperatur tubuh, tekanan darah, usia, dan beberapa pengujian kesehatan lainnya.

Pada PMI Kec. Tanjung Morawa pernah terjadi kesalahan dalam mempertimbangkan kelayakan calon pendonor yang dikhawatirkan menimbulkan efek negatif pada kesehatan pendonor setelah mendonorkan 
darahnya. Bidang ilmu Sistem Pendukung Keputusan hadir sebagai solusi untuk mengatasi permasalahan tersebut.

Dalam penelitian Sistem Pendukung Keputusan kali ini, digunakan metode SMART (Simple Multi Attribute Rating Technique) untuk menentukan calon pendonor darah pada Palang Merah Indonesia (PMI) Kecamatan Tanjung Morawa. Adapun metode SMART (Simple Multi Attribute Rating Technique) adalah metode dalam pengambilan keputusan multi atribut. Teknik pengambilan keputusan multi atribut ini digunakan untuk mendukung pembuat keputusan dalam memilih beberapa alternatif. Setiap pembuat keputusan harus memiliki sebuah alternatif yang sesuai dengan tujuan yang dirumuskan. Metode SMART lebih banyak digunakan karena kesederhanaanya dalam merespon kebutuhan pembuat keputusan dan caranya menganalisa respon. Analisa yang terlibat adalah transparan, metode ini memberikan pemahaman masalah yang tinggi dan dapat diterima oleh pembuat keputusan. Sehingga metode SMART (Simple Multi Attribute Rating Technique) merupakan metode yang tepat untuk diterapkan dalam penyelesaian masalah keputusan.

\section{METODE PENELITIAN}

\subsection{Sistem Pendukung Keputusan}

Menurut para ahli atau sumber menerangkan bahwa "Sistem Pendukung Keputusan / Decision Support Sistem (DSS) merupakan sistem informasi interaktif yang menyediakan informasi, pemodelan, dan pemanipulasian data. Sistem itu digunakan untuk membantu pengambilan keputusan dalam situasi yang semiterstruktur dan situasi yang tidak terstruktur, dimana tak seorang pun tahu secara pasti bagaimana keputusan saharusnya dibuat" (menurut Alter dalam kusrini, 2007:15).

Sedangkan sumber lain menerangkan bahwa "Sistem Pendukung Keputusan adalah sistem berbasis komputer yang terdiri dari tiga komponen yang saling berinteraksi, sistem bahasa (mekanisme untuk memberi komunikasi antara pengguna dan komponen sistem pendukung lain), sistem pengetahuan (repositori pengetahuan domain masalah yang ada pada sistem pendukung keputusan atau sebagai data atau sebagai prosedur), dan sistem pemrosesan masalah (hubungan antara dua komponen lainnya, terdiri dari satu atau lebih kapabilitas manipulasi masalah umum yang diperlukan untuk pengambilan keputusan)" (menurut Bonczek, dkk dalam Nofriansyah, Dicky 2014:1).

Sehingga dapat diperoleh bahwa Sistem pendukung keputusan adalah Sistem Informasi interaktif yang menyediakan informasi, pemodelan, dan pemanipulasian data. Sistem itu digunakan untuk membantu pengambilan keputusan dalam situasi yang semi terstruktur dan situasi yang tidak terstruktur, dimana tak seorang pun tahu secara pasti keputusan seharusnya dibuat.

Konsep dasar sistem pendukung keputusan merupakan sebuah sistem yang mampu memberikan kemampuan, baik kemampuan memecahkan masalah maupun mengkomunikasikan untuk masalah semi terstruktur. Sistem Pendukung Keputusan merupakan pengembangan lebih lanjut dari sistem informasi manajemen terkomputerisasi.

\subsection{Simple Multi Attribute Rating Technique (SMART)}

Banyak metode yang dapat digunakan dalam sistem pendukung keputusan. Salah satu metode tersebut yang digunakan adalah metode Simple Multi Attribute Rating Technique (SMART). Metode ini merupakan metode pengambilan keputusan multi kriteria yang dikembangkan oleh Edward pada tahun 1977. Teknik pengambilan keputusan multi kriteria ini didasarkan pada teori bahwa setiap alternatif terdiri dari sejumlah kriteria yang memiliki nilai - nilai dan setiap kriteria memiliki bobot yang menggambarkan seberapa penting ia dibandingkan dengan kriteria lain. Pembobotan ini digunakan untuk menilai setiap alternatif agar diperoleh alternative terbaik. SMART menggunakan linear additive model untuk meramal nilai setiap alternatif. SMART merupakan metode pengambilan keputusan yang fleksibel.[6]

Setiap atribut mempunyai bobot yang menggambarkan seberapa penting dibandingkan dengan atribut lain. Pembobotan dan pemberian peringkat ini digunakan untuk menilai setiap alternatif agar diperoleh alternatif terbaik. Pembobotan pada metode Simple Multi Attribute Rating Technique (SMART) menggunakan skala antara 0 sampai 1, sehingga mempermudah perhitungan dan perbandingan nilai pada masing-masing alternatif. (Nofriansyah, Dicky 2017 : 27)

Model yang digunakan oleh metode SMART adalah seperti berikut:

$$
\mathrm{U}\left(\mathrm{a}_{\mathrm{i}}\right)=\sum_{j=1}^{w} W j U i(a i)
$$

Keterangan :

$\mathrm{W}_{\mathrm{j}} \quad=$ Nilai Pembobotan Kriteria ke-j dan K-Kriteria

U(ai) = Nilai utility kriteria ke-1 untuk kriteria ke-i

Dimana $\mathrm{i} \quad=1,2, \ldots \ldots \ldots \mathrm{m}$

\subsection{Donor Darah}

Penyumbang darah atau Donor darah adalah proses pengambilan darah dari seseorang secara sukarela atau pengganti untuk disimpan di bank darah sebagai stok darah kemudian digunakan untuk transfusi darah. 
Untuk menekankan pentingnya persediaan darah hasil sumbangan, penyumbangan darah biasa dilakukan rutin di Unit Donor Darah (UDD) Palang Merah Indonesia (PMI) Pusat maupun Unit Donor Darah di daerah.

Dan setiap beberapa waktu, ada pula penggalangan penyumbangan darah yang diadakan di tempattempat keramaian, seperti di pusat perbelanjaan, kantor perusahaan besar, tempat ibadah, serta sekolah dan universitas secara sukarela. Pada acara ini, para calon penyumbang dapat menyempatkan datang dan menyumbang tanpa harus mengkhususkan diri mendatangi pusat penyumbangan darah dengan memanfaatkan sistem informasi atau secara online. Selain itu, bank darah dapat memiliki mobil penyumbangan darah (mobile unit) yang digunakan untuk tempat menyumbang.

Pada Palang Merah Indonesia (PMI) Kec. Tanjung Morawa pendonoran darah biasanya dilakukan di dalam kegiatan-kegiatan sosial yang diselenggarakan oleh Palang Merah Indonesia (PMI) Kec. Tanjung Morawa ataupun oleh sekolah, perusahaan, organaisasi-organisasi kemasyarakatan (ormas) yang bekerjasama dengan PMI Kec. Tanjung Morawa. Sebelum melakukan pendonoran darah calon pendonor darah biasanya akan melewati beberapa tahapan (diperiksa) sampai akhirnya memperoleh keputusan ia layak atau tidak layak untuk dapat menjadi pendonor darah.

\section{ANALISIS DAN HASIL}

Pada saat ini proses pengambilan keputusan calon pendonor darah di Palang Merah Indonesia (PMI) Kecamatan Tanjung Morawa masih ditentukan oleh keputusan secara manual yaitu dengan medical checkup (tes kesehatan). Dimana dalam penyeleksian terkadang masih sering terdapat beberapa calon pendonor yang diizinkan mendonor tetapi tidak sesuai dengan persyaratan yang ditetapkan oleh PMI Pusat. Padahal darah merupakan bagian terpenting dalam kehidupan manusia. Jika salah dalam pelaksanaannya dapat berakibat fatal bagi pasien yang memerlukan darah. Dari hasil analisis permasalahan tersebut, perlu adanya suatu metode sistem pendukung keputusan yang mampu menentukan calon pendonor darah yang tepat dan akurat sehingga dapat membantu pihak Palang Merah Indonesia (PMI) dalam mengambil keputusan.

\subsection{Algoritma Sistem}

Langkah-langkah yang dilakukan di dalam melakukan permodelan untuk algoritma SMART pada penelitian ini adalah sebagai berikut:

1. Menentukan jumlah kriteria dari keputusan yang akan diambil, Dalam sistem pendukung keputusan penentuan calon pendonor darah, pihak Palang Merah Indonesia (PMI) Kecamatan Tanjung Morawa menetapkan kriteria-kriteria yang digunakan sebagai acuan untuk penilaian dalam pengambilan keputusan. Kriteria-kriteria tersebut dapat dilihat pada tabel di bawah ini :

Tabel 3.1 Kriteria-Kriteria Yang Ditetapkan Pihak PMI Kecamatan Tanjung Morawa

\begin{tabular}{|c|l|c|}
\hline No & \multicolumn{1}{|c|}{ Nama Kriteria } & Nilai Bobot \\
\hline 1 & Usia $(\mathrm{C} 1)$ & $15 \%$ \\
\hline 2 & Berat Badan $(\mathrm{C} 2)$ & $15 \%$ \\
\hline 3 & Tekanan Darah $(\mathrm{C} 3)$ & $25 \%$ \\
\hline 4 & Temperatur Tubuh $(\mathrm{C} 4)$ & $20 \%$ \\
\hline 5 & Hemoglobin $(\mathrm{HB})$ Darah $(\mathrm{C} 5)$ & $25 \%$ \\
\hline
\end{tabular}

(Sumber : Palang Merah Indonesia (PMI) Kecamatan Tanjung Morawa)

a. Kriteria Usia (C1)

Berdasarkan kriteria yang dibutuhkan untuk pengambilan keputusan berdasarkan usia, maka kriteria usia yang telah diubah dalam bentuk rating. Adapun nilai kriteria usia yaitu :

Tabel 3.2 Kriteria Usia

\begin{tabular}{|c|c|}
\hline Usia (Tahun) & Nilai \\
\hline$\leq 17$ & 100 \\
\hline $31-40$ & 90 \\
\hline $41-50$ & 80 \\
\hline$>50$ & 70 \\
\hline
\end{tabular}

b. Kriteria Berat Badan (C2) 
Berdasarkan kriteria yang dibutuhkan untuk pengambilan keputusan berdasarkan berat badan, maka kriteria berat badan yang telah diubah dalam bentuk rating. Adapun nilai kriteria berat badan yaitu :

Tabel 3.3 Kriteria Berat Badan

\begin{tabular}{|c|c|}
\hline Berat Badan (Kg) & Nilai \\
\hline$\leq 46$ & 100 \\
\hline $51-56$ & 75 \\
\hline $57-62$ & 50 \\
\hline$>62$ & 25 \\
\hline
\end{tabular}

c. Kriteria Tekanan Darah (C3)

Berdasarkan kriteria yang dibutuhkan untuk pengambilan keputusan berdasarkan tekanan darah, maka kriteria tekanan darah yang telah diubah dalam bentuk rating. Adapun nilai kriteria tekanan darah yaitu :

Tabel 3.4 Kriteria Tekanan Darah

\begin{tabular}{|c|c|}
\hline Tekanan Darah & Nilai \\
\hline$\leq 113 / 75 \mathrm{mmHg}$ & 100 \\
\hline $115 / 75 \mathrm{mmHg}-115 / 80 \mathrm{mmHg}$ & 75 \\
\hline $117 / 78 \mathrm{mmHg}-118 / 78 \mathrm{mmHg}$ & 50 \\
\hline$>118 / 78 \mathrm{mmHg}$ & 25 \\
\hline
\end{tabular}

d. Kriteria Temperatur Tubuh (C4)

Berdasarkan kriteria yang dibutuhkan untuk pengambilan keputusan berdasarkan temperatur tubuh, maka kriteria temperatur tubuh yang telah diubah dalam bentuk rating. Adapun nilai kriteria temperatur tubuh yaitu :

Tabel 3.5 Kriteria Temperatur Tubuh

\begin{tabular}{|c|c|}
\hline Temperatur Tubuh & Nilai \\
\hline $36,5^{\circ} \mathrm{C}-36,7^{\circ} \mathrm{C}$ & 100 \\
\hline $36,8^{\circ} \mathrm{C}-37,0^{\circ} \mathrm{C}$ & 90 \\
\hline $37,1^{\circ} \mathrm{C}-37,3^{\circ} \mathrm{C}$ & 80 \\
\hline$>37,3{ }^{\circ} \mathrm{C}$ & 70 \\
\hline
\end{tabular}

e. Kriteria Hemoglobin (HB) Darah (C5)

Berdasarkan kriteria yang dibutuhkan untuk pengambilan keputusan berdasarkan hemoglobin $(H B)$ darah, maka kriteria hemoglobin $(H B)$ darah yang telah diubah dalam bentuk rating. Adapun nilai kriteria hemoglobin $(H B)$ darah yaitu :

Tabel 3.6 Kriteria Hemoglobin (HB) Darah

\begin{tabular}{|c|c|}
\hline Hemoglobin $(\boldsymbol{H B})$ Darah & Nilai \\
\hline$>18 \mathrm{gr} / \mathrm{dL}$ & 100 \\
\hline $18-16 \mathrm{gr} / \mathrm{dL}$ & 75 \\
\hline $15-13 \mathrm{gr} / \mathrm{dL}$ & 50 \\
\hline$\leq 13 \mathrm{gr} / \mathrm{dL}$ & 25 \\
\hline
\end{tabular}


2. Selanjutnya, sistem secara default memberikan nilai 0-100 berdasarkan prioritas dengan melakukan normalisasi.

Fungsi dari normalisasi adalah untuk menghitung rating kinerja ternormalisasi dari kriteria yang telah disebutkan diatas dengan menggunakan rumus :

\section{$\frac{\mathrm{W}_{\mathrm{j}}}{\sum \mathrm{W}_{\mathrm{j}}}$}

Dari rumus diatas maka didapatkan normalisasi sebagai berikut :

Tabel 3.7 Normalisasi

\begin{tabular}{|c|l|c|c|}
\hline Kriteria & \multicolumn{1}{|c|}{ Keterangan } & Bobot & Normalisasi \\
\hline C1 & Usia & $15 \%$ & 0.15 \\
\hline C2 & Berat Badan & $15 \%$ & 0.15 \\
\hline C3 & Tekanan Darah & $25 \%$ & 0.25 \\
\hline C4 & Temperatur Tubuh & $20 \%$ & 0.20 \\
\hline C5 & Hemoglobin $(H B)$ Darah & $25 \%$ & 0.25 \\
\hline
\end{tabular}

3. Memberikan nilai kriteria untuk setiap alternatif.

Berikut ini merupakan data alternatif yang didapat berdasarkan data yang diambil dari Palang Merah Indonesia (PMI) Kecamatan Tanjung Morawa :

Tabel 3.8 Data Awal

\begin{tabular}{|c|l|c|c|c|c|c|}
\hline \multirow{2}{*}{ No } & \multirow{2}{*}{ Nama Alternatif } & \multicolumn{5}{|c|}{ Nilai Bobot Kriteria } \\
\cline { 3 - 7 } & & $\mathbf{C 1}$ & $\mathbf{C 2}$ & $\mathbf{C 3}$ & $\mathbf{C 4}$ & C5 \\
\hline 1 & Ibnu Hajar & 49 & 70 & $120 / 75 \mathrm{mmHg}$ & 36.6 & 15 \\
\hline 2 & Endah Eva Yanti & 40 & 68 & $110 / 60 \mathrm{mmHg}$ & 36.9 & 13 \\
\hline 3 & Mhd. Ridwan & 58 & 54 & $114 / 60 \mathrm{mmHg}$ & 36.8 & 14 \\
\hline 4 & Hengki Syahputra & 33 & 75 & $113 / 75 \mathrm{mmHg}$ & 37.0 & 17 \\
\hline 5 & Paiman & 35 & 85 & $115 / 75 \mathrm{mmHg}$ & 36.9 & 18 \\
\hline 6 & Hasmiyanti & 35 & 55 & $130 / 80 \mathrm{mmHg}$ & 36.8 & 13 \\
\hline 7 & Ditha Gusmita & 22 & 50 & $117 / 85 \mathrm{mmHg}$ & 37.2 & 15 \\
\hline 8 & Widi Asri & 32 & 48 & $130 / 75 \mathrm{mmHg}$ & 36.8 & 13 \\
\hline 9 & Siti Sundari & 26 & 46 & $115 / 80 \mathrm{mmHg}$ & 36.8 & 16 \\
\hline 10 & Deswita Andayani & 34 & 57 & $115 / 75 \mathrm{mmHg}$ & 37.0 & 14 \\
\hline
\end{tabular}

(Sumber : Palang Merah Indonesia (PMI) Kecamatan Tanjung Morawa)

Selanjutnya kriteria akan diubah kedalam bentuk nilai.

Tabel 3.9 Penilaian Kriteria untuk Setiap Alternatif

\begin{tabular}{|c|l|c|c|c|c|c|}
\hline \multirow{2}{*}{ Kode } & \multirow{2}{*}{ Alternatif } & \multicolumn{5}{c|}{ Kriteria } \\
\cline { 3 - 6 } & & C1 & C2 & C3 & C4 & C5 \\
\hline A1 & Ibnu Hajar & 80 & 25 & 25 & 100 & 50 \\
\hline A2 & Endah Eva Yanti & 90 & 25 & 100 & 90 & 50 \\
\hline A3 & Mhd. Ridwan & 70 & 75 & 100 & 90 & 50 \\
\hline A4 & Hengky Syahputra & 90 & 25 & 100 & 90 & 75 \\
\hline A5 & Paiman & 90 & 25 & 75 & 90 & 75 \\
\hline A6 & Hasmiyanti & 90 & 75 & 25 & 90 & 50 \\
\hline A7 & Ditha Gusmita & 100 & 100 & 50 & 80 & 50 \\
\hline A8 & Widi Asri & 90 & 100 & 25 & 90 & 50 \\
\hline A9 & Siti Sundari & 100 & 100 & 75 & 90 & 75 \\
\hline A10 & Deswita Andayani & 90 & 50 & 75 & 90 & 50 \\
\hline
\end{tabular}

4. Menghitung nilai utility untuk setiap kriteria masing-masing 
Nilai utility diperlukan pada saat perangkingan tiap alternatif, sehingga dapat diketahui alternatif mana yang layak atau tidak layak untuk dipilih. Untuk menghitung nilai utility digunakan rumus :

Keterangan :

$$
\mathrm{u}_{\mathrm{i}}\left(a_{\mathrm{i}}\right)=100 \frac{(\text { Cmax }- \text { Count } i)}{\left(C \max -C_{\text {min }}\right)} \%
$$

$\mathrm{U}_{\mathrm{i}}\left(\mathrm{a}_{\mathrm{i}}\right) \quad=$ Nilai utility kriteria ke-1 untuk kriteria ke-i

$\mathrm{C}_{\max } \quad=$ Nilai kriteria maksimal

$\mathrm{C}_{\min }=$ Nilai kriteria minimal

$\mathrm{C}_{\text {ount } \mathrm{i}}=$ Nilai kriteria ke-i

Berikut perhitungan nilai utility dari setiap alternatif :

a. Nilai Utility dari A1 :

Tabel 3.10 Nilai Utility dari A1

\begin{tabular}{|c|l|c|l|}
\hline No & \multicolumn{1}{|c|}{ Kriteria } & Penilaian & \multicolumn{1}{|c|}{$\mathbf{u}_{\mathbf{i}}\left(\boldsymbol{\alpha}_{\mathrm{i}}\right)$} \\
\hline 1 & Usia (C1) & 80 & $=100 \frac{100-80}{100-0}=20$ \\
\hline 2 & Berat Badan (C2) & 25 & $=100 \frac{100-25}{100-0}=75$ \\
\hline 3 & Tekanan Darah (C3) & 25 & $=100 \frac{100-25}{100-0}=75$ \\
\hline 4 & Temperatur Tubuh (C4) & 100 & $=100 \frac{100-100}{100-0}=0$ \\
\hline 5 & Hemoglobin (HB) Darah (C5) & 50 & $=100 \frac{100-50}{100-0}=50$ \\
\hline
\end{tabular}

b. Nilai Utility dari A2 :

Tabel 3.11 Nilai Utility dari A2

\begin{tabular}{|c|l|c|l|}
\hline No & \multicolumn{1}{|c|}{ Kriteria } & Penilaian & \multicolumn{1}{c|}{$\mathbf{u}_{\mathbf{i}}\left(\boldsymbol{\alpha}_{\mathrm{i}}\right)$} \\
\hline 1 & Usia (C1) & 90 & $=100 \frac{100-90}{100-0}=10$ \\
\hline 2 & Berat Badan (C2) & 25 & $=100 \frac{100-25}{100-0}=75$ \\
\hline 3 & Tekanan Darah (C3) & 100 & $=100 \frac{100-100}{100-0}=0$ \\
\hline 4 & Temperatur Tubuh (C4) & 90 & $=100 \frac{100-90}{100-0}=10$ \\
\hline 5 & Hemoglobin $(H B)$ Darah (C5) & 50 & $=100 \frac{100-50}{100-0}=50$ \\
\hline
\end{tabular}

c. Nilai Utility dari A3 :

Tabel 3.12 Nilai Utility dari A3

\begin{tabular}{|c|l|c|l|}
\hline No & \multicolumn{1}{|c|}{ Kriteria } & Penilaian & $\mathbf{u}_{i}\left(\boldsymbol{a}_{\mathbf{i}}\right)$ \\
\hline 1 & Usia $(\mathrm{C} 1)$ & 70 & $=100 \frac{100-70}{100-0}=30$ \\
\hline 2 & Berat Badan (C2) & 75 & $=100 \frac{100-75}{100-0}=25$ \\
\hline
\end{tabular}




\begin{tabular}{|c|l|c|l|}
\hline 3 & Tekanan Darah (C3) & 100 & $=100 \frac{100-100}{100-0}=0$ \\
\hline 4 & Temperatur Tubuh (C4) & 90 & $=100 \frac{100-90}{100-0}=10$ \\
\hline 5 & Hemoglobin $(H B)$ Darah (C5) & 50 & $=100 \frac{100-50}{100-0}=50$ \\
\hline
\end{tabular}

d. Nilai Utility dari A4:

Tabel 3.13 Nilai Utility dari A4

\begin{tabular}{|c|l|c|l|}
\hline No & \multicolumn{1}{|c|}{ Kriteria } & Penilaian & \multicolumn{1}{|c|}{$\mathbf{u}_{\mathbf{i}}\left(\boldsymbol{a}_{\mathbf{i}}\right)$} \\
\hline 1 & Usia (C1) & 90 & $=100 \frac{100-90}{100-0}=10$ \\
\hline 2 & Berat Badan (C2) & 25 & $=100 \frac{100-25}{100-0}=75$ \\
\hline 3 & Tekanan Darah (C3) & 100 & $=100 \frac{100-100}{100-0}=0$ \\
\hline 4 & Temperatur Tubuh (C4) & 90 & $=100 \frac{100-90}{100-0}=10$ \\
\hline 5 & Hemoglobin (HB) Darah (C5) & 75 & $=100 \frac{100-75}{100-0}=25$ \\
\hline
\end{tabular}

e. Nilai Utility dari A5 :

Tabel 3.14 Nilai Utility dari A5

\begin{tabular}{|c|l|c|l|}
\hline No & \multicolumn{1}{|c|}{ Kriteria } & Penilaian & $\mathbf{u}_{\mathbf{i}}\left(\boldsymbol{a}_{\mathbf{i}}\right)$ \\
\hline 1 & Usia $(\mathrm{C} 1)$ & 90 & $=100 \frac{100-90}{100-0}=10$ \\
\hline 2 & Berat Badan (C2) & 25 & $=100 \frac{100-25}{100-0}=75$ \\
\hline 3 & Tekanan Darah (C3) & 75 & $=100 \frac{100-75}{100-0}=25$ \\
\hline 4 & Temperatur Tubuh $(\mathrm{C} 4)$ & 90 & $=100 \frac{100-90}{100-0}=10$ \\
\hline 5 & Hemoglobin $(H B)$ Darah $(\mathrm{C} 5)$ & 75 & $=100 \frac{100-75}{100-0}=25$ \\
\hline
\end{tabular}

f. Nilai Utility dari A6 :

Tabel 3.15 Nilai Utility dari A6

\begin{tabular}{|c|l|c|l|}
\hline No & \multicolumn{1}{|c|}{ Kriteria } & Penilaian & $\mathbf{u}_{\mathbf{i}}\left(\boldsymbol{a}_{\mathbf{i}}\right)$ \\
\hline 1 & Usia $(\mathrm{C} 1)$ & 90 & $=100 \frac{100-90}{100-0}=10$ \\
\hline 2 & Berat Badan (C2) & 75 & $=100 \frac{100-75}{100-0}=25$ \\
\hline 3 & Tekanan Darah (C3) & 25 & $=100 \frac{100-25}{100-0}=75$ \\
\hline
\end{tabular}




\begin{tabular}{|c|l|c|l|}
\hline 4 & Temperatur Tubuh (C4) & 90 & $=100 \frac{100-90}{100-0}=10$ \\
\hline 5 & Hemoglobin (HB) Darah (C5) & 50 & $=100 \frac{100-50}{100-0}=50$ \\
\hline
\end{tabular}

g. Nilai Utility dari A7 :

Tabel 3.16 Nilai Utility dari A7

\begin{tabular}{|c|l|c|l|}
\hline No & \multicolumn{1}{|c|}{ Kriteria } & Penilaian & $\mathbf{u}_{\mathbf{i}}\left(\boldsymbol{a}_{\mathbf{i}}\right)$ \\
\hline 1 & Usia (C1) & 100 & $=100 \frac{100-100}{100-0}=0$ \\
\hline 2 & Berat Badan (C2) & 100 & $=100 \frac{100-100}{100-0}=0$ \\
\hline 3 & Tekanan Darah (C3) & 50 & $=100 \frac{100-50}{100-0}=50$ \\
\hline 4 & Temperatur Tubuh (C4) & 80 & $=100 \frac{100-80}{100-0}=20$ \\
\hline 5 & Hemoglobin (HB) Darah (C5) & 50 & $=100 \frac{100-50}{100-0}=50$ \\
\hline
\end{tabular}

h. Nilai Utility dari A8:

Tabel 3.17 Nilai Utility dari A8

\begin{tabular}{|c|l|c|l|}
\hline No & \multicolumn{1}{|c|}{ Kriteria } & Penilaian & \multicolumn{1}{|c|}{$\mathbf{u}_{\mathbf{i}}\left(\boldsymbol{a}_{\mathbf{i}}\right)$} \\
\hline 1 & Usia (C1) & 90 & $=100 \frac{100-90}{100-0}=10$ \\
\hline 2 & Berat Badan (C2) & 100 & $=100 \frac{100-100}{100-0}=0$ \\
\hline 3 & Tekanan Darah (C3) & 25 & $=100 \frac{100-25}{100-0}=75$ \\
\hline 4 & Temperatur Tubuh (C4) & 90 & $=100 \frac{100-90}{100-0}=10$ \\
\hline 5 & Hemoglobin $(H B)$ Darah (C5) & 50 & $=100 \frac{100-50}{100-0}=50$ \\
\hline
\end{tabular}

i. Nilai Utility dari A9:

Tabel 3.18 Nilai Utility dari A9

\begin{tabular}{|c|l|c|l|}
\hline No & \multicolumn{1}{|c|}{ Kriteria } & Penilaian & $\mathbf{u}_{\mathbf{i}}\left(\boldsymbol{a}_{\mathbf{i}}\right)$ \\
\hline 1 & Usia $(\mathrm{C} 1)$ & 100 & $=100 \frac{100-100}{100-0}=0$ \\
\hline 2 & Berat Badan (C2) & 100 & $=100 \frac{100-100}{100-0}=0$ \\
\hline 3 & Tekanan Darah (C3) & 75 & $=100 \frac{100-75}{100-0}=25$ \\
\hline
\end{tabular}




\begin{tabular}{|c|l|c|l|}
\hline 4 & Temperatur Tubuh (C4) & 90 & $=100 \frac{100-90}{100-0}=10$ \\
\hline 5 & Hemoglobin $(H B)$ Darah (C5) & 75 & $=100 \frac{100-75}{100-0}=25$ \\
\hline
\end{tabular}

j. Nilai Utility dari A10 :

Tabel 3.19 Nilai Utility dari A10

\begin{tabular}{|c|l|c|l|}
\hline No & \multicolumn{1}{|c|}{ Kriteria } & Penilaian & $\mathbf{u}_{\mathbf{i}}\left(\boldsymbol{a}_{\mathbf{i}}\right)$ \\
\hline 1 & Usia (C1) & 90 & $=100 \frac{100-90}{100-0}=10$ \\
\hline 2 & Berat Badan (C2) & 50 & $=100 \frac{100-50}{100-0}=50$ \\
\hline 3 & Tekanan Darah (C3) & 75 & $=100 \frac{100-75}{100-0}=25$ \\
\hline 4 & Temperatur Tubuh (C4) & 90 & $=100 \frac{100-90}{100-0}=10$ \\
\hline 5 & Hemoglobin (HB) Darah (C5) & 50 & $=100 \frac{100-50}{100-0}=50$ \\
\hline
\end{tabular}

Maka setelah perhitungan selesai akan didapat nilai Utility pada setiap alternatif seperti tabel berikut ini:

Tabel 3.20 Hasil Nilai Utility Setiap Alternatif

$\begin{array}{lcccccccccc}\text { A } & \mathbf{C 1} & \mathbf{C 2} & \mathbf{C 3} & \mathbf{C 4} & \mathbf{C 5} & \begin{array}{c}\text { Ui (ai) } \\ \text { C1 }\end{array} & \begin{array}{c}\text { Ui (ai) } \\ \mathbf{C 2}\end{array} & \begin{array}{c}\text { Ui (ai) } \\ \mathbf{C 3}\end{array} & \begin{array}{c}\text { Ui (ai) } \\ \mathbf{C 4}\end{array} & \begin{array}{c}\text { Ui (ai) } \\ \text { C5 }\end{array} \\ \text { A1 } & 80 & 25 & 25 & 100 & 50 & 20 & 75 & 75 & 0 & 50 \\ \text { A2 } & 90 & 25 & 100 & 90 & 50 & 10 & 75 & 0 & 10 & 50 \\ \text { A3 } & 70 & 75 & 100 & 90 & 50 & 30 & 25 & 0 & 10 & 50 \\ \text { A4 } & 90 & 25 & 100 & 90 & 75 & 10 & 75 & 0 & 10 & 25 \\ \text { A5 } & 90 & 25 & 75 & 90 & 75 & 10 & 75 & 25 & 10 & 25 \\ \text { A6 } & 90 & 75 & 25 & 90 & 50 & 10 & 25 & 75 & 10 & 50 \\ \text { A7 } & 100 & 100 & 50 & 80 & 50 & 0 & 0 & 50 & 20 & 50 \\ \text { A8 } & 90 & 100 & 25 & 90 & 50 & 10 & 0 & 75 & 10 & 50 \\ \text { A9 } & 100 & 100 & 75 & 90 & 75 & 0 & 0 & 25 & 10 & 25 \\ \text { A10 } & 90 & 50 & 75 & 90 & 50 & 10 & 50 & 25 & 10 & 50\end{array}$

5. Menghitung Nilai Akhir dan Melakukan Perangkingan

Setelah menghitung nilai utility $\mathrm{u}_{\mathrm{i}}\left(a_{\mathrm{i}}\right)$ dari setiap alternatif maka dilanjutkan menghitung nilai keseluruhan utility u $\left(a_{\mathrm{i}}\right)$ dengan menggunakan rumus:

$$
u(a i) \sum \frac{m}{j=1} w j \cdot u i(a i)
$$

a. Nilai Keseluruhan Utility $\mathrm{U}\left(\mathrm{a}_{\mathrm{i}}\right)$ dari A1: 
Tabel 3.21 Nilai Keseluruhan Utility dari A1

\begin{tabular}{|c|l|l|c|c|}
\hline No & \multicolumn{1}{|c|}{ Kriteria } & \multicolumn{1}{|c|}{$\mathbf{u}_{\mathbf{i}}\left(\boldsymbol{a}_{\mathbf{i}}\right)$} & $\mathbf{W}_{\mathbf{j}}$ & $\mathbf{U}\left(\mathbf{a}_{\mathbf{i}}\right)$ \\
\hline 1 & Usia (C1) & $=100 \frac{100-80}{100-0}=20$ & 0.15 & 3 \\
\hline 2 & Berat Badan (C2) & $=100 \frac{100-25}{100-0}=75$ & 0.15 & 11.25 \\
\hline 3 & Tekanan Darah (C3) & $=100 \frac{100-25}{100-0}=75$ & 0.25 & 18.75 \\
\hline 4 & Temperatur Tubuh (C4) & $=100 \frac{100-100}{100-0}=0$ & 0.20 & 0 \\
\hline 5 & Hemoglobin (HB) Darah (C5) & $=100 \frac{100-50}{100-0}=50$ & 0.25 & 12.5 \\
\hline \multicolumn{2}{|c|}{ Total Nilai Utility Keseluruhan dari A1 } & \\
\hline
\end{tabular}

b. Nilai Keseluruhan Utility $\mathrm{U}\left(\mathrm{a}_{\mathrm{i}}\right)$ dari $\mathrm{A} 2$ :

Tabel 3.22 Nilai Keseluruhan Utility dari A2

\begin{tabular}{|c|c|c|c|c|}
\hline No & Kriteria & $\mathbf{u}_{\mathrm{i}}\left(\boldsymbol{a}_{\mathrm{i}}\right)$ & $\mathbf{W}_{\mathbf{j}}$ & $\mathbf{U}\left(\mathbf{a}_{\mathbf{i}}\right)$ \\
\hline 1 & Usia $(\mathrm{C} 1)$ & $=100 \frac{100-90}{100-0}=10$ & 0.15 & 1.5 \\
\hline 2 & Berat Badan (C2) & $=100 \frac{100-25}{100-0}=75$ & 0.15 & 11.25 \\
\hline 3 & Tekanan Darah (C3) & $=100 \frac{100-100}{100-0}=0$ & 0.25 & 0 \\
\hline 4 & Temperatur Tubuh (C4) & $=100 \frac{100-90}{100-0}=10$ & 0.20 & 2 \\
\hline 5 & Hemoglobin $(H B)$ Darah (C5) & $=100 \frac{100-50}{100-0}=50$ & 0.25 & 12.5 \\
\hline \multicolumn{4}{|c|}{ Total Nilai Utility Keseluruhan dari A2 } & 27.25 \\
\hline
\end{tabular}

c. Nilai Keseluruhan Utility $\mathrm{U}\left(\mathrm{a}_{\mathrm{i}}\right)$ dari A3:

Tabel 3.23 Nilai Keseluruhan Utility dari A3

\begin{tabular}{|c|c|c|c|c|}
\hline No & Kriteria & $\mathbf{u}_{\mathrm{i}}\left(\boldsymbol{\alpha}_{\mathrm{i}}\right)$ & $\mathbf{W}_{\mathbf{j}}$ & $\mathbf{U}\left(\mathbf{a}_{\mathbf{i}}\right)$ \\
\hline 1 & Usia $(\mathrm{C} 1)$ & $=100 \frac{100-70}{100-0}=30$ & 0.15 & 4.5 \\
\hline 2 & Berat Badan (C2) & $=100 \frac{100-75}{100-0}=25$ & 0.15 & 3.75 \\
\hline 3 & Tekanan Darah (C3) & $=100 \frac{100-100}{100-0}=0$ & 0.25 & 0 \\
\hline 4 & Temperatur Tubuh (C4) & $=100 \frac{100-90}{100-0}=10$ & 0.20 & 2 \\
\hline 5 & Hemoglobin (HB) Darah (C5) & $=100 \frac{100-50}{100-0}=50$ & 0.25 & 12.5 \\
\hline \multicolumn{4}{|c|}{ Total Nilai Utility Keseluruhan dari A3 } & 22.75 \\
\hline
\end{tabular}


d. Nilai Keseluruhan Utility $\mathrm{U}\left(\mathrm{a}_{\mathrm{i}}\right)$ dari A4:

Tabel 3.24 Nilai Keseluruhan Utility dari A4

\begin{tabular}{|c|c|c|c|c|}
\hline No & Kriteria & $\mathbf{u}_{\mathrm{i}}\left(\boldsymbol{a}_{\mathrm{i}}\right)$ & $\mathbf{W}_{\mathbf{j}}$ & $\mathbf{U}\left(\mathbf{a}_{\mathbf{i}}\right)$ \\
\hline 1 & Usia $(\mathrm{C} 1)$ & $=100 \frac{100-90}{100-0}=10$ & 0.15 & 1.5 \\
\hline 2 & Berat Badan (C2) & $=100 \frac{100-25}{100-0}=75$ & 0.15 & 11.25 \\
\hline 3 & Tekanan Darah (C3) & $=100 \frac{100-100}{100-0}=0$ & 0.25 & 0 \\
\hline 4 & Temperatur Tubuh (C4) & $=100 \frac{100-90}{100-0}=10$ & 0.20 & 2 \\
\hline 5 & Hemoglobin (HB) Darah (C5) & $=100 \frac{100-75}{100-0}=25$ & 0.25 & 6.25 \\
\hline \multicolumn{4}{|c|}{ Total Nilai Utility Keseluruhan dari A4 } & 21 \\
\hline
\end{tabular}

e. Nilai Keseluruhan (Utility) $\mathrm{U}\left(\mathrm{a}_{\mathrm{i}}\right)$ dari A5:

Tabel 3.25 Nilai Keseluruhan Utility dari A5

\begin{tabular}{|c|c|c|c|c|}
\hline No & Kriteria & $\mathbf{u}_{\mathbf{i}}\left(\boldsymbol{\alpha}_{\mathrm{i}}\right)$ & $\overline{\mathbf{W}_{\mathbf{j}}}$ & $\mathbf{U}\left(\mathbf{a}_{\mathbf{i}}\right)$ \\
\hline 1 & Usia (C1) & $=100 \frac{100-90}{100-0}=10$ & 0.15 & 1.5 \\
\hline 2 & Berat Badan (C2) & $=100 \frac{100-25}{100-0}=75$ & 0.15 & 11.25 \\
\hline 3 & Tekanan Darah (C3) & $=100 \frac{100-75}{100-0}=25$ & 0.25 & 6.25 \\
\hline 4 & Temperatur Tubuh (C4) & $=100 \frac{100-90}{100-0}=10$ & 0.20 & 2 \\
\hline 5 & Hemoglobin (HB) Darah (C5) & $=100 \frac{100-75}{100-0}=25$ & 0.25 & 6.25 \\
\hline \multicolumn{4}{|c|}{ Total Nilai Utility Keseluruhan dari A5 } & 27.25 \\
\hline
\end{tabular}

f. Nilai Keseluruhan Utility $\mathrm{U}\left(\mathrm{a}_{\mathrm{i}}\right)$ dari A6:

Tabel 3.26 Nilai Keseluruhan Utility dari A6

\begin{tabular}{|c|l|l|c|c|}
\hline No & \multicolumn{1}{|c|}{ Kriteria } & \multicolumn{1}{|c|}{$\mathbf{u}_{\mathbf{i}}\left(\boldsymbol{\alpha}_{\mathbf{i}}\right)$} & $\mathbf{W}_{\mathbf{j}}$ & $\mathbf{U}\left(\mathbf{a}_{\mathbf{i}}\right)$ \\
\hline 1 & Usia (C1) & $=100 \frac{100-90}{100-0}=10$ & 0.15 & 1.5 \\
\hline 2 & Berat Badan (C2) & $=100 \frac{100-75}{100-0}=25$ & 0.15 & 3.75 \\
\hline 3 & Tekanan Darah (C3) & $=100 \frac{100-25}{100-0}=75$ & 0.25 & 18.75 \\
\hline 4 & Temperatur Tubuh (C4) & $=100 \frac{100-90}{100-0}=10$ & 0.20 & 2 \\
\hline
\end{tabular}




\begin{tabular}{|c|l|l|c|c|}
\hline 5 & Hemoglobin $(\mathrm{HB})$ Darah (C5) & $=100 \frac{100-50}{100-0}=50$ & 0.25 & 12.5 \\
\hline \multicolumn{3}{|c|}{ Total Nilai Utility Keseluruhan dari A6 } & $\mathbf{3 8 . 5}$ \\
\hline
\end{tabular}

g. Nilai Keseluruhan Utility $\mathrm{U}\left(\mathrm{a}_{\mathrm{i}}\right)$ dari A7:

Tabel 3.27 Nilai Keseluruhan Utility dari A7

\begin{tabular}{|c|l|l|c|c|}
\hline No & \multicolumn{1}{|c|}{ Kriteria } & \multicolumn{1}{|c|}{$\mathbf{u}_{\mathbf{i}}\left(\boldsymbol{a}_{\mathbf{i}}\right)$} & $\mathbf{W}_{\mathbf{j}}$ & $\mathbf{U}\left(\mathbf{a}_{\mathbf{i}}\right)$ \\
\hline 1 & Usia (C1) & $=100 \frac{100-100}{100-0}=0$ & 0.15 & 0 \\
\hline 2 & Berat Badan (C2) & $=100 \frac{100-100}{100-0}=0$ & 0.15 & 0 \\
\hline 3 & Tekanan Darah (C3) & $=100 \frac{100-80}{100-0}=20$ & 0.20 & 4 \\
\hline 4 & Temperatur Tubuh (C4) & $=100 \frac{100-50}{100-0}=50$ & 0.25 & 12.5 \\
\hline 5 & $\begin{array}{l}\text { Hemoglobin (HB) Darah (C5) } \\
\text { Total Nilai Utility Keseluruhan dari A7 }\end{array}$ & $\mathbf{2 9}$ \\
\hline \multicolumn{4}{|c|}{} \\
\hline
\end{tabular}

h. Nilai Keseluruhan Utility $\mathrm{U}\left(\mathrm{a}_{\mathrm{i}}\right)$ dari A8:

Tabel 3.28 Nilai Keseluruhan Utility dari A8

\begin{tabular}{|c|l|l|c|c|}
\hline No & \multicolumn{1}{|c|}{ Kriteria } & \multicolumn{1}{|c|}{$\mathbf{u}_{\mathbf{i}}\left(\boldsymbol{a}_{\mathbf{i}}\right)$} & $\mathbf{W}_{\mathbf{j}}$ & $\mathbf{U}\left(\mathbf{a}_{\mathbf{i}}\right)$ \\
\hline 1 & Usia (C1) & $=100 \frac{100-90}{100-0}=10$ & 0.15 & 1.5 \\
\hline 2 & Berat Badan (C2) & $=100 \frac{100-100}{100-0}=0$ & 0.15 & 0 \\
\hline 3 & Tekanan Darah (C3) & $=100 \frac{100-25}{100-0}=75$ & 0.25 & 18.75 \\
\hline 4 & $\begin{array}{l}\text { Temperatur Tubuh (C4) } \\
\text { 5 }\end{array}$ & $\begin{array}{l}\text { Hemoglobin (HB) Darah (C5) } \\
\text { Total Nilai Utility Keseluruhan dari A8 }\end{array}$ & 0.20 & 2 \\
\hline \multicolumn{2}{|c|}{$=100 \frac{100-50}{100-0}=50$} & 0.25 & 12.5 \\
\hline
\end{tabular}

i. Nilai Keseluruhan Utility $\mathrm{U}\left(\mathrm{a}_{\mathrm{i}}\right)$ dari A9:

Tabel 3.29 Nilai Keseluruhan Utility dari A9

\begin{tabular}{|c|l|l|c|c|}
\hline No & \multicolumn{1}{|c|}{ Kriteria } & \multicolumn{1}{|c|}{$\mathbf{u}_{\mathbf{i}}\left(\boldsymbol{a}_{\mathbf{i}}\right)$} & $\mathbf{W}_{\mathbf{j}}$ & $\mathbf{U}\left(\mathbf{a}_{\mathbf{i}}\right)$ \\
\hline 1 & Usia $(\mathrm{C} 1)$ & $=100 \frac{100-100}{100-0}=0$ & 0.15 & 0 \\
\hline 2 & Berat Badan (C2) & $=100 \frac{100-100}{100-0}=0$ & 0.15 & 0 \\
\hline 3 & Tekanan Darah (C3) & $=100 \frac{100-75}{100-0}=25$ & 0.25 & 6.25 \\
\hline
\end{tabular}




\begin{tabular}{|c|l|l|c|c|}
\hline 4 & Temperatur Tubuh (C4) & $=100 \frac{100-90}{100-0}=10$ & 0.20 & 2 \\
\hline 5 & Hemoglobin $(H B)$ Darah (C5) & $=100 \frac{100-75}{100-0}=25$ & 0.25 & 6.25 \\
\hline \multicolumn{2}{|r|}{ Total Nilai Utility Keseluruhan dari A9 } & $\mathbf{1 4 . 5}$ \\
\hline
\end{tabular}

j. Nilai Keseluruhan Utility $\mathrm{U}\left(\mathrm{a}_{\mathrm{i}}\right)$ dari A10:

Tabel 3.30 Nilai Keseluruhan Utility dari A10

\begin{tabular}{|c|c|c|c|c|}
\hline No & Kriteria & $\mathbf{u}_{\mathrm{i}}\left(\boldsymbol{\alpha}_{\mathrm{i}}\right)$ & $\mathbf{W}_{\mathbf{j}}$ & $\mathbf{U}\left(\mathbf{a}_{\mathbf{i}}\right)$ \\
\hline 1 & Usia (C1) & $=100 \frac{100-90}{100-0}=10$ & 0.15 & 1.5 \\
\hline 2 & Berat Badan (C2) & $=100 \frac{100-50}{100-0}=50$ & 0.15 & 7.5 \\
\hline 3 & Tekanan Darah (C3) & $=100 \frac{100-75}{100-0}=25$ & 0.25 & 6.25 \\
\hline 4 & Temperatur Tubuh (C4) & $=100 \frac{100-90}{100-0}=10$ & 0.20 & 2 \\
\hline 5 & Hemoglobin (HB) Darah (C5) & $=100 \frac{100-50}{100-0}=50$ & 0.25 & 12.5 \\
\hline \multicolumn{4}{|c|}{ Total Nilai Utility Keseluruhan dari A10 } & 29.75 \\
\hline
\end{tabular}

Setelah proses perhitungan Nilai Utility Keseluruhan $U\left(\mathrm{a}_{\mathrm{i}}\right)$ selesai maka hasil nilai yang didapat dari keseluruhan Utility pada setiap alternatif sebagai berikut :

Tabel 3.31 Hasil Nilai Keseluruhan Utility

\begin{tabular}{|c|l|c|}
\hline Kode & \multicolumn{1}{|c|}{ Alternatif } & Nilai Akhir \\
\hline A1 & Ibnu Hajar & 45.5 \\
\hline A2 & Endah Eva Yanti & 27.25 \\
\hline A3 & Mhd. Ridwan & 22.75 \\
\hline A4 & Hengki Syahputra & 21 \\
\hline A5 & Paiman & 27.25 \\
\hline A6 & Hasmiyanti & 38.5 \\
\hline A7 & Ditha Gusmita & 29 \\
\hline A8 & Widi Asri & 34.75 \\
\hline A9 & Siti Sundari & 14.5 \\
\hline A10 & Deswita Andayani & 29.75 \\
\hline
\end{tabular}

Calon pendonor darah yang dinyatakan layak adalah calon pendonor yang memiliki hasil nilai akhir tertinggi hingga terendah. Adapun sesuai dengan kasus diatas maka yang dijadikan prioritas adalah nilai yang tertinggi dengan menentukan batas nilai kelayakan $\leq 29$. Berdasarkan nilai akhir diatas, berikut ini hasil keputusannya :

Tabel 3.32 Hasil Keputusan

\begin{tabular}{|c|l|c|c|l|}
\hline Kode & \multicolumn{1}{|c|}{ Alternatif } & Nilai Akhir & Rangking & \multicolumn{1}{c|}{ Keputusan } \\
\hline A1 & Ibnu Hajar & 45.5 & $\# 1$ & Layak \\
\hline A6 & Hasmiyanti & 38.5 & $\# 2$ & Layak \\
\hline A8 & Widi Asri & 34.75 & $\# 3$ & Layak \\
\hline A10 & Deswita Andayani & 29.75 & $\# 4$ & Layak \\
\hline
\end{tabular}




\begin{tabular}{|l|l|c|c|l|} 
A7 & Ditha Gusmita & 29 & $\# 5$ & Layak \\
\hline A2 & Endah Eva Yanti & 27.25 & $\# 6$ & Tidak Layak \\
\hline A5 & Paiman & 27.25 & $\# 7$ & Tidak Layak \\
\hline A3 & Mhd. Ridwan & 22.75 & $\# 8$ & Tidak Layak \\
\hline A4 & Hengki Syahputra & 21 & $\# 9$ & Tidak Layak \\
\hline A9 & Siti Sundari & 14.5 & $\# 10$ & Tidak Layak \\
\hline
\end{tabular}

Alternatif A2 memiliki nilai akhir yang sama dengan alternatif A5. Alternatif A2 lebih diutamakan menjadi pendonor darah dikarenakan memiliki nilai utility kriteria hemoglobin darah (C5) lebih tinggi daripada alternatif A5.

Hasil keputusan yang didapat hanya untuk membantu pihak Palang Merah Indonesia (PMI) Kecamatan Tanjung Morawa dalam menentukan calon pendonor darah. Hasil keputusan berdasarkan metode Simple Multi Attribute Rating Technique (SMART) bukan menjadi keputusan final, sehingga keputusan tetap berada pada Palang Merah Indonesia (PMI) Kecamatan Tanjung Morawa.

\subsection{Implementasi Program}

Form data menentukan calon pendonor darah adalah form yang digunakan untuk mengetahui datadata dari calon pendonor darah. Juga berfungsi untuk menambah, mengubah dan menghapus data-data calon pendonor darah yang ada pada database.

Form login adalah tampilan pertama ketika user menjalankan aplikasi. Pada form ini berisikan nama pengguna (username) dan kata sandi (password) yang harus diisi terlebih dahulu untuk membuka aplikasi. Berikut tampilan form login dari aplikasi yang dirancang:

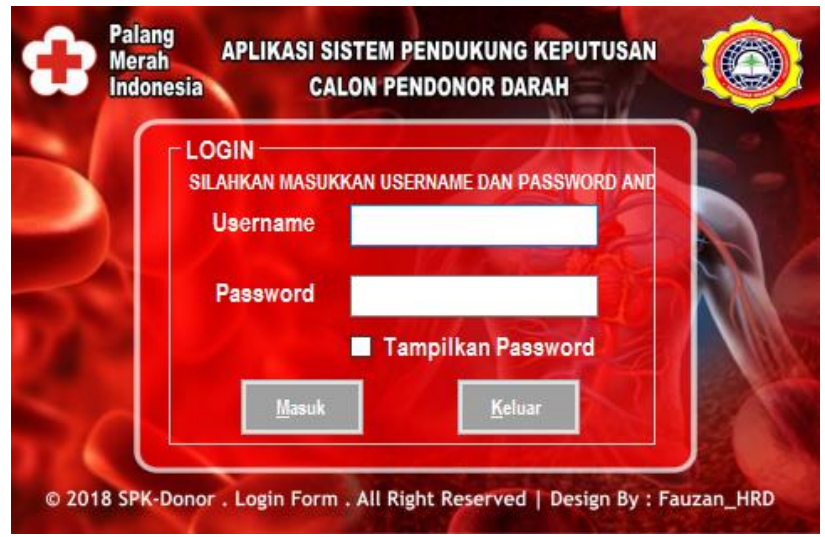

Form menu utama adalah tampilan navigasi. Didalamnya terdapat menu-menu untuk membuka form lainnya. Form menu utama akan muncul jika sudah berhasil login. Berikut tampilan form menu utama dari aplikasi yang dirancang:

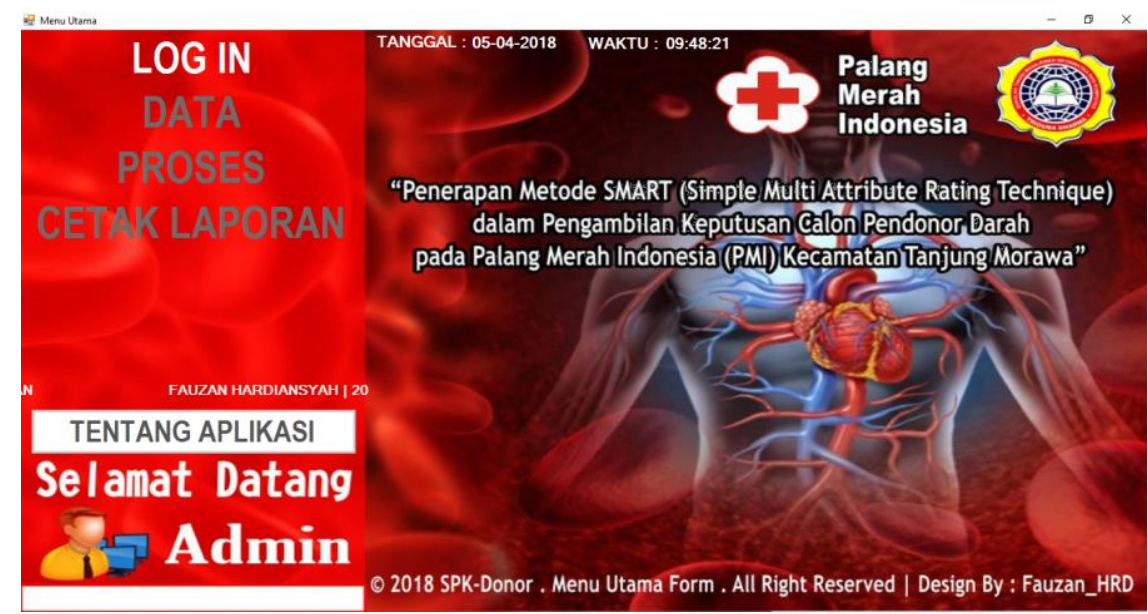

Gambar 2. Tampilan Form Menu Utama 
Form Calon Pendonor digunakan untuk menginputkan data calon pendonor darah. Berikut tampilan form calon pendonor dari aplikasi yang dirancang:

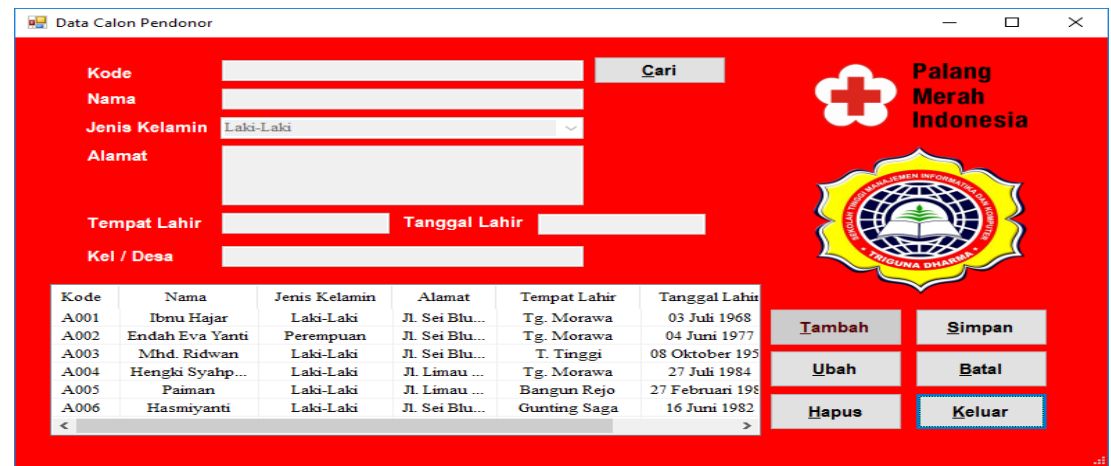

Gambar 3. Tampilan Form Calon Pendonor

Form Kriteria digunakan untuk menginputkan nilai kriteria. Pada aplikasi ini kriteria sudah ditentukan oleh sistem, berdasarkan hasil riset. Jadi, user hanya dapat mengubah nilai bobot untuk masing-masing kriteria.

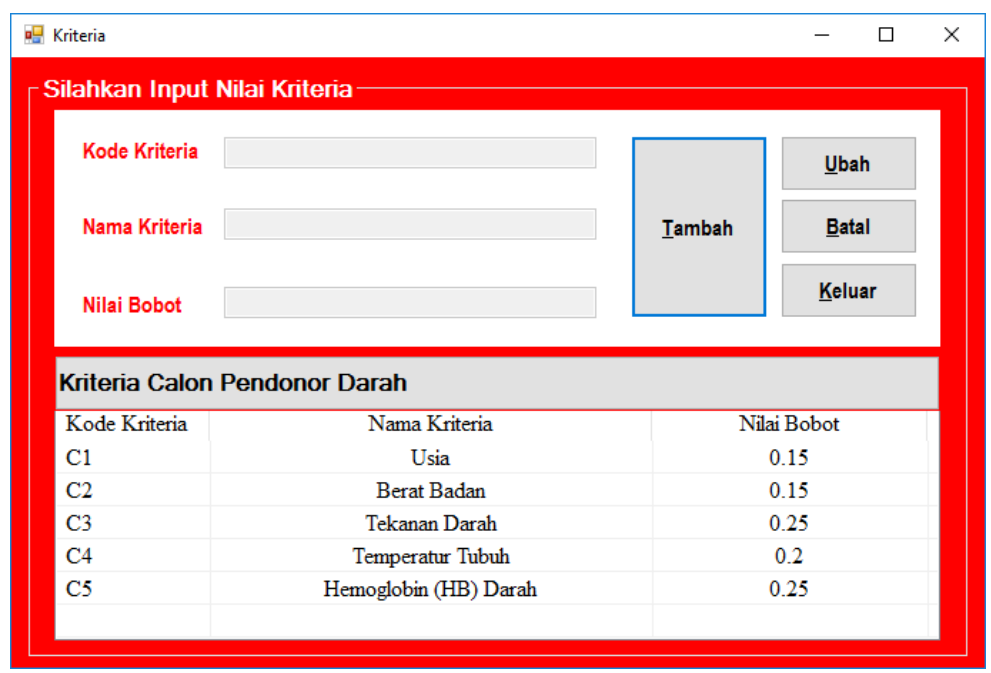

Gambar 4. Tampilan Form Kriteria

Form Hasil Medical Check Up digunakan untuk menginputkan data hasil dari medical check up calon pendonor darah. Berikut tampilan form hasil medical check up dari aplikasi yang dirancang:

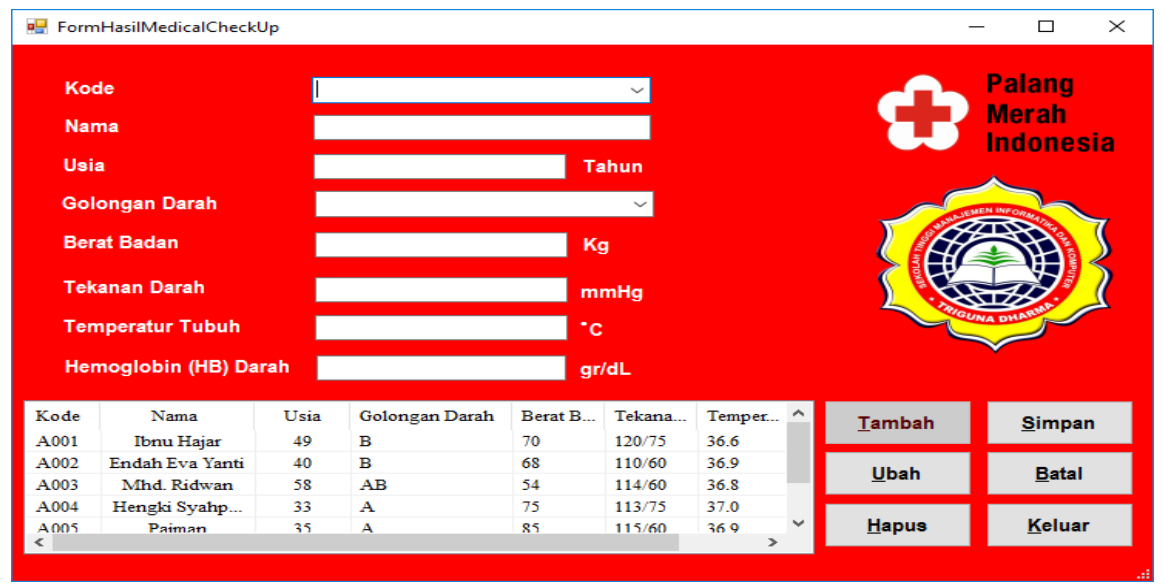

Gambar 5. Tampilan Form Hasil Medical Check Up

Form penilaian digunakan untuk menginputkan nilai dari hasil medical check up yang kemudian dikonversi kedalam nilai bobot yang telah ditentukan di sistem. Berikut tampilan form penilaian dari aplikasi yang dirancang: 


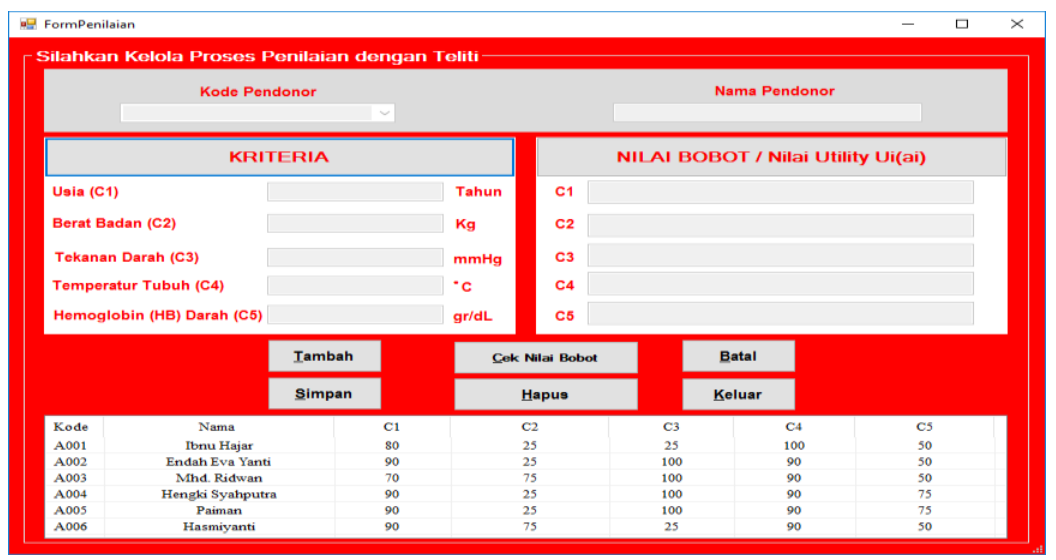

Gambar 6. Tampilan Form Penilaian

Form perhitungan digunakan untuk memproses dan menghitung data sehingga menghasilkan sebuah keputusan menggunakan metode SMART. Berikut tampilan form perhitungan dari aplikasi yang dirancang:

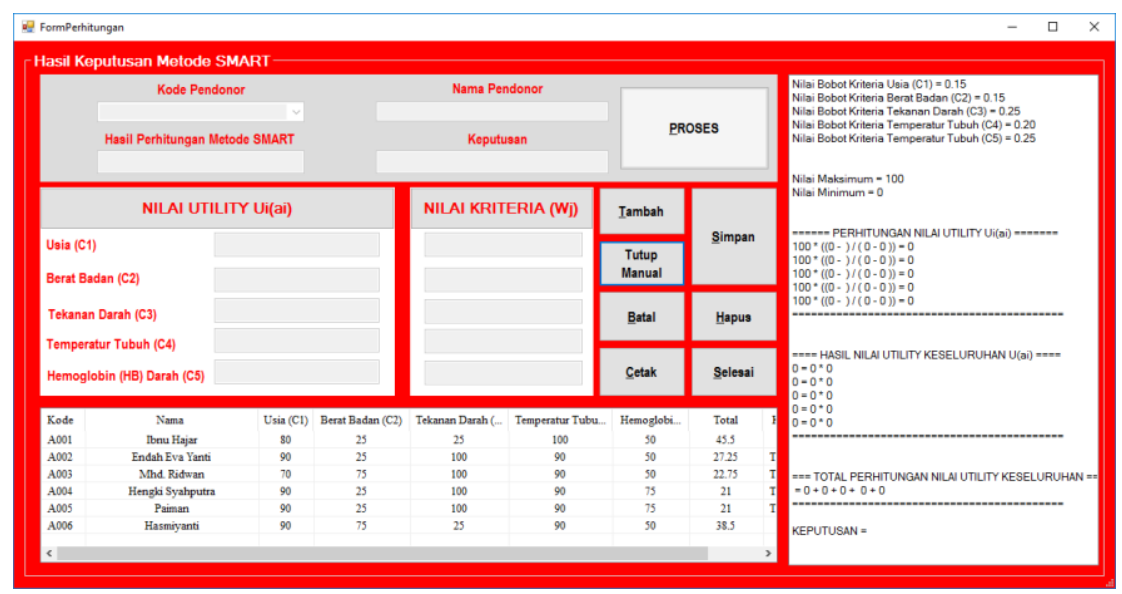

Gambar 7. Tampilan Form Perhitungan

Laporan Keputusan digunakan untuk menampilkan data keseluruhan calon pendonor darah. Berikut tampilan form laporan keputusan dari aplikasi yang dirancang:

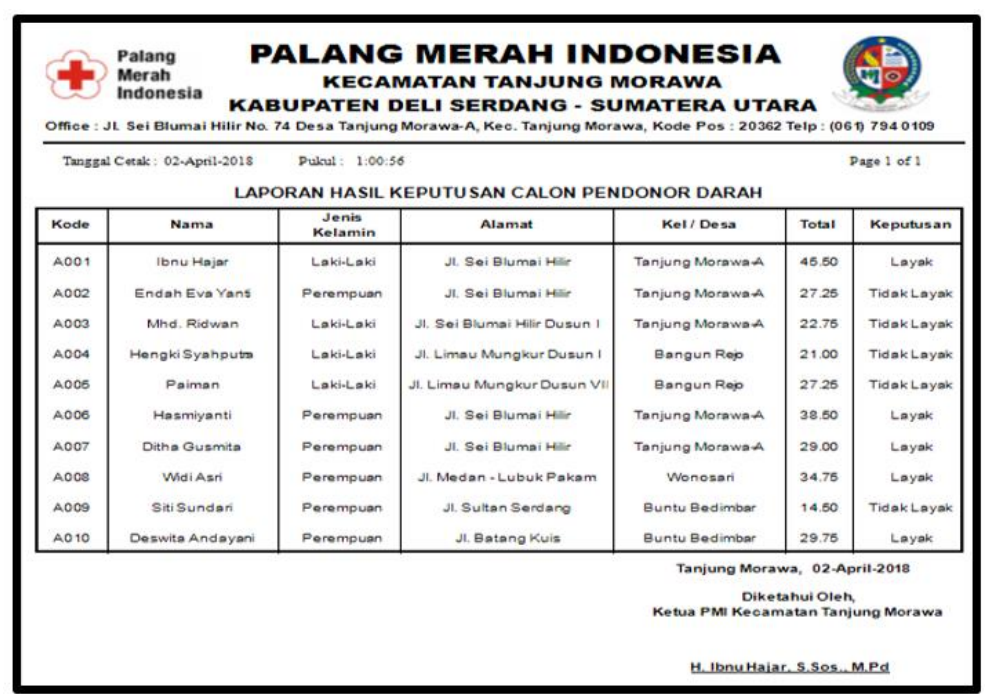

Gambar 8. Tampilan Laporan Keputusan Calon Pendonor Darah 


\section{KESIMPULAN}

1. Berdasarkan hasil analisa permasalahan yang terjadi berkenaan dengan penentuan calon pendonor darah, permasalahan dapat diselesaikan dengan menerapkan metode SMART.

2. Berdasarkan hasil perancangan aplikasi yang mengadopsi metode $S M A R T$, penentuan calon pendonor darah dapat ditentukan secara cepat dan tepat.

3. Perancangan aplikasi penentuan calon pendonor darah dapat dilakukan dengan pengkodean menggunakan bahasa pemrograman berbasis Dekstop Programming.

4. Berdasarkan hasil uji sistem yang telah dirancang, sistem mampu memecahkan permasalahan di dalam penentuan calon pendonor darah.

5. Terdapat lima kriteria yang ditentukan pihak Palang Merah Indonesia (PMI) Kecamatan Tanjung Morawa, yaitu usia, berat badan, tekanan darah, temperatur tubuh, dan hemoglobin $(H B)$ darah.

\section{UCAPAN TERIMA KASIH}

Puji syukur kehadirat Allah SWT atas izin-Nya yang telah melimpahkan rahmat, taufik dan hidayah-Nya sehingga dapat menyelesaikan jurnal ilmiah ini dengan baik. Ucapan terima kasih teristimewa ditujukan untuk kepada kedua orang tua Ayahanda Chairil Anwar Masari, S.T. dan Ibunda Sri Suharyati, yang telah mengasuh, membesarkan dan selalu memberikan doa, motivasi serta pengorbanan baik bersifat moril maupun materil yang tidak terhingga selama menjalani pendidikan. Ucapan terima kasih yang sebesar-besarnya juga ditujukan terutama kepada Bapak Rudi Gunawan, SE., M.Si., selaku Ketua Sekolah Tinggi Manajemen Informatika Dan Komputer (STMIK) Triguna Dharma Medan. Bapak Zulfian Azmi, ST., M.Kom., selaku Wakil Ketua I Bidang Akademik STMIK Triguna Dharma Medan. Bapak Marsono, S.Kom., M.Kom., selaku Ketua Program Studi Sistem Informasi STMIK Triguna Dharma Medan. Bapak Ahmad Fitri Boy, S.Kom., M.Kom., selaku Dosen Pembimbing I yang telah memberikan saran, arahan dan dukungannya serta motivasi, sehingga penelitian ini dapat terselesaikan dengan baik dan tepat waktu. Bapak Jufri Halim,S.E., M.M., selaku Dosen Pembimbing II yang telah memberikan bimbingan tata cara penulisan, saran dan motivasi sehingga penelitian ini dapat terselesaikan dengan baik dan tepat waktu. Seluruh Dosen, Staff dan Pegawai di STMIK Triguna Dharma Medan. Bapak H. Ibnu Hajar,S.Sos., M.Pd, selaku Ketua Palang Merah Indonesia (PMI) Kecamatan Tanjung Morawa yang telah mengizinkan melakukan riset guna memenuhi data dan bahan yang dibutuhkan dalam menyelesaikan kasus yang diangkat dan seluruh teman-teman di STMIK Triguna Dharma Medan yang telah berbagi dalam suka maupun duka dan membantu hingga terselesaikannya penelitian ini.

\section{REFERENSI}

[1] Kusrini, 2007. Konsep Dan Aplikasi Sistem Pendukung Keputusan. Yogyakarta: Andi.

[2] Nofriansyah. D. 2017. Multi Criteria Decision Making (MCDM) pada Sistem Pendukung Keputusan. Yogyakarta: DeePublish.

[3] Nofriansyah. D. 2014. Konsep Data Mining VS Sistem Pendukung Keputusan. Yogyakarta: DeePublish.

[4] Rosa, A. S., \& Shalahuddin, M. 2013. Rekayasa Perangkat Lunak Terstruktur dan Berorientasi Objek. Bandung: Informatika.

[5] Sulindawati, \& Fathoni, M. 2010. Pengantar Analisa Perancangan Sistem. Jurnal Saintikom. 9 (2). $14-$ 15.

[6] Yeni Purnamasari, et al. 2017. Sistem Penilaian Kinerja Dosen Teladan Menggunakan Metode Simple Multi Attribute Rating Technique (SMART). Jurnal Teknologi Elektro. 8(1), 18

[7] http://diagram-uml.blogspot.co.id/2012/09/use-case-diagram.html Ditemukenali 28 Februari 2018 https://hellosehat.com/pusat-kesehatan/hipertensi-tekanan-darahtinggi/pengertian-tekanan-darah-adalah/ Ditemukenali 15 April 2018 